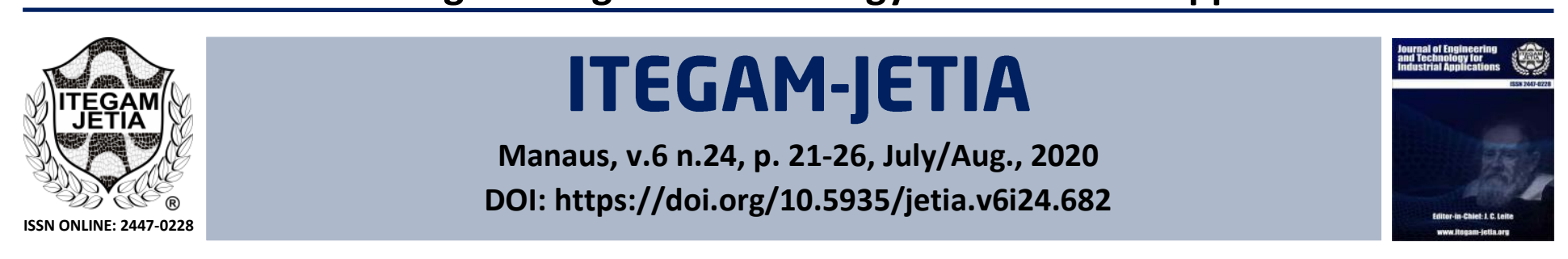

\title{
ADSORPTION KINETICS OF PHENOL FROM AQUEOUS SOLUTION USING SUGARCANE BAGASSE ASH AS LOW-COST ADSORBENT MATERIAL
}

\section{Yan Miguel Gallo, Francisca Mónica Calero de Hoces² ${ }^{2}$ Iván Leandro Rodríguez Ricoª María Ángeles Martín Lara ${ }^{4}$ and Julio Omar Prieto García ${ }^{5}$}

${ }^{1}$ Cienfuegos Center for Environmental Studies. Cienfuegos, Cuba.

${ }^{2,4}$ Department of Chemical Engineering, Faculty of Sciences, University of Granada. Granada, Spain.

${ }^{3,5}$ Faculty of Chemistry-Pharmacy, Central University "Marta Abreu" of Las Villas. Santa Clara, Cuba.

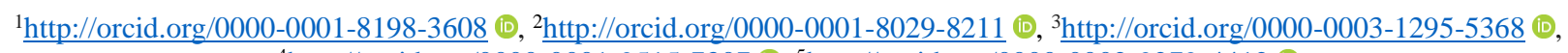
${ }^{4}$ http://orcid.org/0000-0001-9515-7307 @, ${ }^{5}$ http://orcid.org/0000-0002-9279-4412 (

Email: yan@ceac.cu,mcaleroh@ugr.es, ivanl@uclv.edu.cu, marianml@ugr.es,omarpg@uclv.edu.cu

\section{ARTICLE INFO}

\section{Article History}

Received: July $27^{\text {th }}, 2020$

Accepted: August $11^{\text {th }}, 2020$

Published: August $31^{\text {th }}, 2020$

\section{Keywords:}

Kinetic,

Adsorption,

Phenol,

Sugarcane bagasse ash.

\begin{abstract}
The sugarcane bagasse fly ash was used to evaluate its adsorption behavior for phenol removal from aqueous solution at three different temperatures. Adsorption tests were performed in batch reactors and also in fixed-bed columns. Pseudo-first order, pseudosecond order and intraparticle diffusion kinetic models were applied to describe adsorption kinetics in batch systems. The pseudo-second model fitted appropriately the obtained experimental data at the three different temperatures tested. Thomas, Yoon-Nelson, AdamsBohart and Dose-Response mathematical models were tested for describing phenol adsorption in dynamic systems (fixed bed columns). Experimental data were well-fitted to the non-linear form of all these models with high regression coefficients.
\end{abstract}

Copyright (C2016 by authors and Galileo Institute of Technology and Education of the Amazon (ITEGAM). This work is licensed under the Creative Commons Attribution International License (CC BY 4.0).

\section{INTRODUCTION}

Phenols are organic compounds produced and used in different industry such as coke, oil refineries, pharmaceutical and phenolic resin plants [1]. Phenols are widely used and, consequently, they are frequently detected in water. They are some of the most dangerous pollutants and pose an important threat to both environment and human health, even at low concentrations [2-4]. The discharge of phenolic waste into watercourses affects to the flora and fauna and the ingestion of small amounts beings may cause affections human health [5]. For all these reasons, phenols are pollutants classified as pollutants of high priority. Consequently, their treatment is very important for safe discharge to the environment. Various methods have been used to remove phenol from aqueous solutions including adsorption, ion exchange, oxidation, precipitation and solvent extraction [6]. Especially adsorption is an interesting technique since it has low cost and is greatly efficient [7], in wastewater treatment. In addition, the cost of operation of the adsorption procedure can be significantly decreased with the use of solid waste adsorbents.
Sugarcane bagasse is a solid waste produced as a consequence of sugar production in industries. The high amounts of sugarcane bagasse generated after the extraction of sucrose from sugarcane has to be treatment and safely disposal. Sugarcane bagasse has been reported as suitable adsorbent material for wastewater treatment and particularly for metal cations removal from wastewaters [8-10]. For example, recently, [10] prepared an activated carbon from sugarcane bagasse and investigated kinetics and mechanisms of $\mathrm{Cr}(\mathrm{VI})$ adsorption onto the carbonaceous material.

Sugarcane bagasse is frequently used as fuel in combustion systems generating new solid waste, mainly two types of ashes: the sugarcane bagasse bottom ashes (SBBA) and the sugarcane bagasse fly ashes (SBFA). Some researchers have analyzed the use of SBFA in civil engineering [11-14]. However, finding other recycling processes to give value to this waste is of great interest. Researchers as [15] performed a complete characterization of sugarcane bagasse ash for its use as adsorbent material. Now, in the present study, the application of SBFA as adsorbent material for the removal of phenol from wastewater was studied. Previously, [16] already used SBFA as adsorbent for 
the removal of phenol from aqueous solution. The previous study showed that the SBFA was an effective adsorbent for the removal of phenol from aqueous solution. However, in the work of [16] only adsorption tests in batch systems were carried out.

In this work, the sorption kinetics of phenol in aqueous solution, in batch and column systems, using SBFA was investigated. Authors consider that the study of kinetics in adsorption processes is important since it clarifies the mechanism of adsorption.

\section{DEVELOPMENT}

\section{II.1 MATERIAL}

Sugarcane bagasse fly ash was collected from the particulate collection devices attached to the boiler furnaces in a Sugar Factory from Villa Clara, Cuba. Then, the ash was sieved using a $1 \mathrm{~mm}$ sieve, dried at $110{ }^{\circ} \mathrm{C}$ for $6 \mathrm{~h}$ and stored in vacuum desiccator, without any pretreatment, for further analyses. A complete characterization of SBFA was performed in a previous work [15] and a summary of the main composition and physical properties was reported in Table 1.

Table 1: Chemical and physical properties of SBFA.

\begin{tabular}{|c|c|c|c|c|c|c|c|c|c|c|c|}
\hline \multicolumn{9}{|c|}{ Chemical properties } & \multicolumn{3}{|c|}{ Physical properties } \\
\hline $\begin{array}{c}\mathrm{Si} \\
(\%)\end{array}$ & $\begin{array}{l}\text { Al } \\
(\%)\end{array}$ & $\begin{array}{c}\mathrm{Fe} \\
(\%)\end{array}$ & $\begin{array}{l}\text { Ca } \\
(\%)\end{array}$ & $\begin{array}{l}\mathrm{Mg} \\
(\%)\end{array}$ & $\begin{array}{c}\mathbf{K} \\
(\%)\end{array}$ & $\begin{array}{c}\text { Organic } \\
\text { matter } \\
(\%)\end{array}$ & $\begin{array}{c}\text { Inorgani } \\
\text { c matter } \\
(\%)\end{array}$ & $\mathrm{pH}_{\mathrm{pzc}}$ & $\begin{array}{c}\text { Bulk } \\
\text { density } \\
\left(\mathrm{g} / \mathrm{cm}^{3}\right)\end{array}$ & $\begin{array}{c}\text { Real } \\
\text { density } \\
\left(\mathbf{g} / \mathbf{c m}^{3}\right)\end{array}$ & $\begin{array}{l}\text { Surfac } \\
\text { e area } \\
\left(\mathrm{m}^{2} / \mathrm{g}\right)\end{array}$ \\
\hline 29.54 & 0.36 & 0.60 & 7.01 & 1.14 & 5.81 & 18.02 & 81.98 & 7.40 & 0.53 & 2.26 & 79.11 \\
\hline
\end{tabular}

Source: Adapted from [15].

\section{II.2 BATCH ADSORPTION EXPERIMENTS}

The $\mathrm{pH}$ of the aqueous solution of phenol was 7.0, this value has been used in other studies [17] and the work temperatures were 27; 40 and $60{ }^{\circ} \mathrm{C}$. For each experimental test, $50 \mathrm{~mL}$ of aqueous solution with a phenol concentration of $50 \mathrm{mg} / \mathrm{L}$ was taken in a 250 $\mathrm{mL}$ flask containing $5 \mathrm{~g}$ of adsorbent; the solution was stirred at a constant shaking rate for 50 minutes and the supernatant liquid was collected at different contact times and analyzed for the residual concentration of phenol using the method ASTM Designation: D 1783 - 01 Standard Test Methods for Phenolic Compounds in Water [18], using a spectrophotometer GENESYS 10S UV-VIS, Thermo Scientific.

Pseudo-first-order, pseudo-second-order and intraparticle diffusion models, were used for analyzing characteristic kinetic parameters of phenol adsorption onto SBFA. A summary of the equations of the models is presented in Table 2 .

Table 2: Summary of the equations of the kinetic models applied in this work for describing phenol ads orption onto SBFA in a batch system.

\begin{tabular}{|c|c|c|c|}
\hline & Pseudo-first-order model & Pseudo-second-order model & Intraparticle diffusion model \\
\hline \multirow{2}{*}{ Equation } & $\frac{d q_{t}}{d t}=k_{1}\left(q_{e}-q_{t}\right)$ & $\frac{d q_{t}}{d t}=k_{2}\left(q_{e}-q_{t}\right)^{2}$ & \multirow{2}{*}{$q_{t}=k_{(i d)} t^{1 / 2}+C$} \\
\hline & $\operatorname{Ln}\left(\frac{\mathrm{q}_{\mathrm{e}}-\mathrm{q}_{\mathrm{t}}}{\mathrm{q}_{\mathrm{e}}}\right)=-\mathrm{k}_{1} \mathrm{t}$ & $\frac{\mathrm{t}}{\mathrm{q}_{\mathrm{t}}}=\frac{1}{\mathrm{k}_{2} \cdot \mathrm{q}_{\mathrm{e}}^{2}}+\frac{\mathrm{t}}{\mathrm{q}_{\mathrm{e}}}$ & \\
\hline Parameters & $\begin{array}{l}\text { where } \mathrm{q}_{\mathrm{e}} \text { and } \mathrm{q}_{\mathrm{t}} \text { are the amounts of } \\
\text { adsorbate uptake per mass of adsorbent, } \\
\mathrm{mg} / \mathrm{g} \text {, at equilibrium and at any time } \mathrm{t} \\
\text { (min), respectively, and } \mathrm{k}_{1}\left(\mathrm{~min}^{-1}\right) \text { is the } \\
\text { rate constant of the pseudo-first order } \\
\text { equation. }\end{array}$ & $\begin{array}{l}\text { where } \mathrm{k}_{2} \text { is the pseudo-second- } \\
\text { order rate constant, } \mathrm{g} /(\mathrm{mg} \cdot \mathrm{min}) \text {. }\end{array}$ & $\begin{array}{l}\text { where, } \mathrm{k}_{(\mathrm{id})} \text { is the intra-particle } \\
\text { diffusion rate constant } \\
\left(\mathrm{mg} / \mathrm{g} \cdot \mathrm{min}^{1 / 2}\right) \text { and } \mathrm{C}(\mathrm{mg} / \mathrm{g}) \text { is a } \\
\text { constant that gives idea about the } \\
\text { thickness of the boundary layer. }\end{array}$ \\
\hline Reference & [19] & [20-21] & [22] \\
\hline
\end{tabular}

\section{II.3 COLUMN ADSORPTION EXPERIMENTS}

Column adsorption studies were developed in a glass column having an internal diameter of $2.3 \mathrm{~cm}$ and $44 \mathrm{~cm}$ height at $27^{\circ} \mathrm{C}$. Experiments were carry out, changing the absorbent mass $(47.5$ y $65.0 \mathrm{~g})$, from these masses was obtained a bed height of 25.0 and $32.5 \mathrm{~cm}$, respectively.
Inlet phenol concentration was $5.0 \mathrm{mg} / \mathrm{L}$ and the flow rate was $0.012 \mathrm{~L} / \mathrm{min}$. The phenol samples were collected every $10 \mathrm{~min}$ and were prepared for concentration determination analyses by spectrophotometry.

Different column kinetic models were used in this study to describe the dynamic behavior of adsorption in the fixed-bed column. A summary of the equations of the models is presented in Table 3. 
Table 3: Summary of the equations of the kinetic models applied in this work for describing phenol adsorption onto SBFA in a fixed-bed column.

\begin{tabular}{|c|c|c|}
\hline Equation & Parameters & Reference \\
\hline$\frac{C}{C_{0}}=e^{K_{A B} C_{0} t-\frac{K_{A B} N_{0} Z}{v}}$ & $\begin{array}{l}\mathrm{K}_{\mathrm{AB}} \text { : kinetic constant, } \mathrm{L} \cdot \mathrm{mg}^{-1} \cdot \mathrm{min}^{-1} \\
\mathrm{~N}_{0} \text { : volumetric adsorption capacity, } \mathrm{mg} \cdot \mathrm{L}^{-1} \\
\mathrm{v} \text { : linear flow rate, } \mathrm{cm} \cdot \mathrm{min}^{-1} \\
\mathrm{Z} \text { : height in the column, } \mathrm{cm}\end{array}$ & Bohart and Adams [23] \\
\hline$\frac{C}{C_{0}}=\frac{1}{1+\exp \left(\frac{K_{T h}}{Q}\left(q_{0} m-C_{0} V_{\text {eff }}\right)\right)}$ & $\begin{array}{l}\mathrm{K}_{\mathrm{Th}} \text { : rate constant, } \mathrm{mL} \mathrm{min}^{-1} \mathrm{mg}^{-1} \\
\mathrm{q}_{0} \text { : maximum concentration of solute in the } \\
\text { solid phase, } \mathrm{mg} \cdot \mathrm{g}^{-1}\end{array}$ & Thomas [24] \\
\hline$\frac{C}{C_{0}}=\frac{1}{1+\exp \left(K_{Y N}(\tau-t)\right)}$ & $\begin{array}{l}\mathrm{K}_{\mathrm{YN}}: \text { rate constant, } \mathrm{min}^{-1} \\
\tau: \text { time required to retain } 50 \% \text { of the initial } \\
\text { adsorbate }\end{array}$ & Yoon and Nelson [25] \\
\hline$\frac{\mathrm{C}}{\mathrm{C}_{0}}=1-\frac{1}{1+\left(\frac{\mathrm{C}_{0} \mathrm{~V}_{\mathrm{eff}}}{\mathrm{q}_{0} \mathrm{~m}}\right)^{\mathrm{a}}}$ & a: empiric parameter & Yan et al. [26] \\
\hline
\end{tabular}

Source: [23-26].

\section{RESULTS AND DISCUSSIONS \\ III.1 BATCH ADSORPTION STUDY}

The relation between the adsorption capacities in function of contact time for different temperatures is shown in Figure 1. The adsorption capacity increased 1.4 times as the contact time increased from 5 to 15 minutes. Also, in the first 5 minutes about $65 \%, 78 \%$ and $65 \%$ of the equilibrium adsorption capacity was reached for 27, 40 and $60{ }^{\circ} \mathrm{C}$, respectively. Qadeer and Rehan reported the phenol adsorption with activated commercial coal and found that the time to reach the equilibrium was five minutes [27-29]. This can be explained by high availability of active sites on the SBFA surface at the beginning of the process [7].

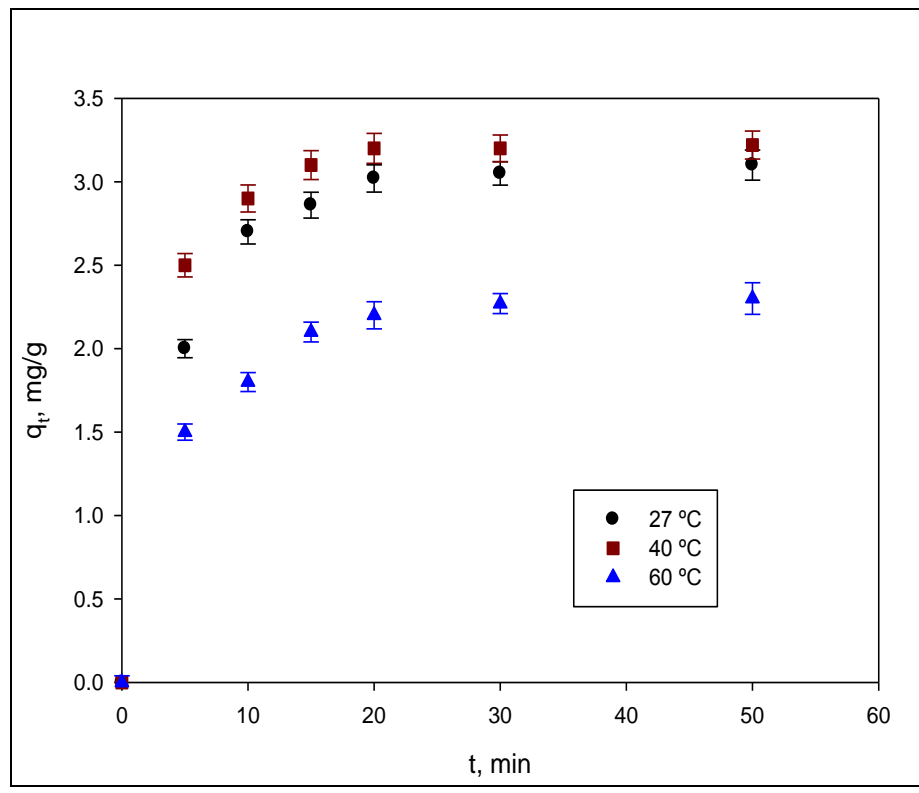

Figure 1: Experimental adsorption capacities in function of contact time at different temperatures.

Source: Authors, (2020).

The experimental results provided in Figure 1 have been fitted by linear regression to the three kinetic models considered in material and methods section: pseudo-first order, pseudosecond order and intraparticle difussion models. Figures 2, 3 and 4 show the results of the fit at the three temperatures tested.

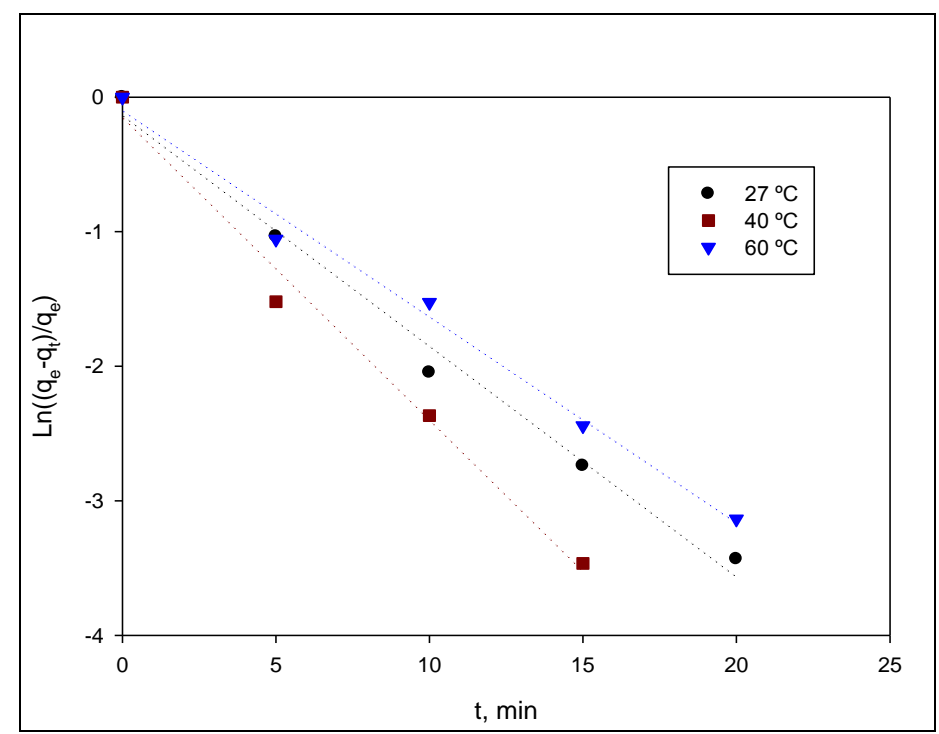

Figure 2: Pseudo-first-order adsorption kinetics of phenol on SBFA.

Source: Authors, (2020).

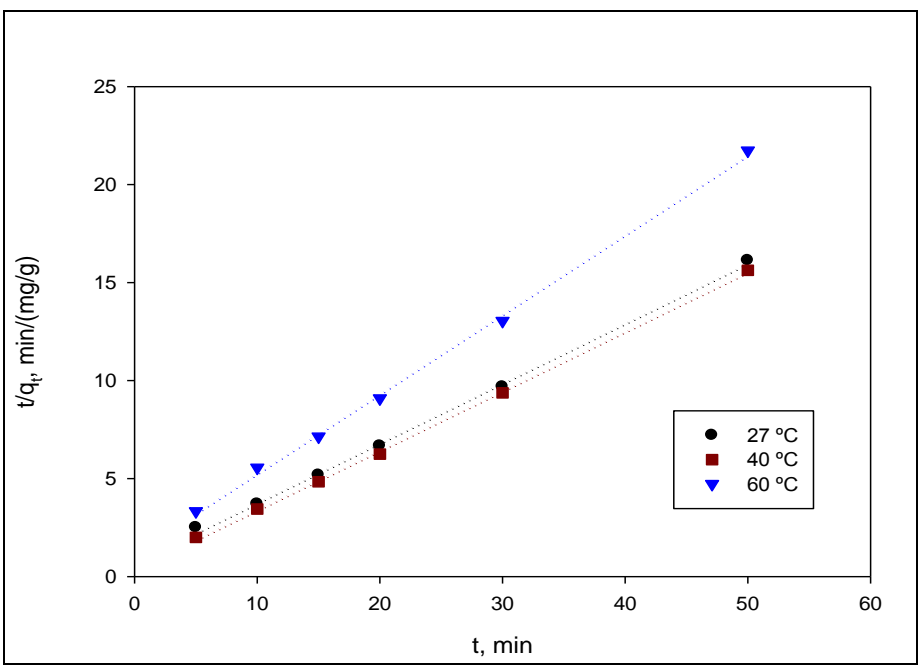

Figure 3: Pseudo-second-order adsorption kinetics of phenol on SBFA.

Source: Authors, (2020). 


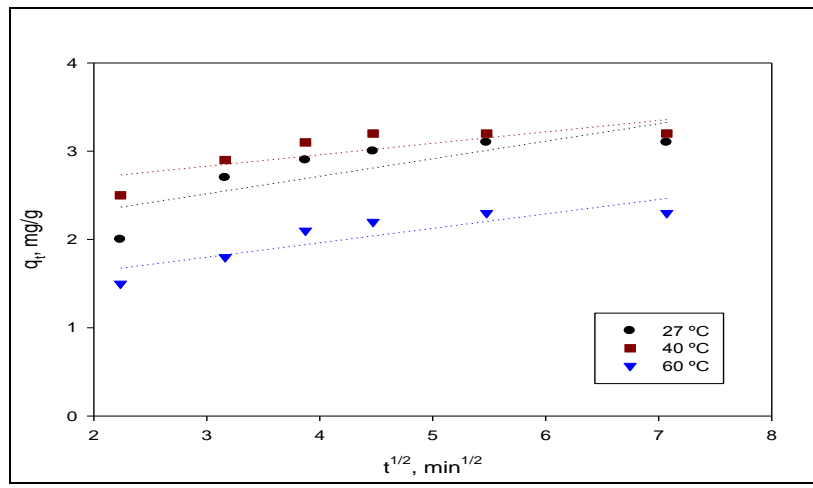

Figure 4: Intraparticle diffusion adsorption kinetics of phenol on SBFA.

Source: Authors, (2020).

Table 4 reports the values of the model parameters calculated from the linear fitting. Results show that, in pseudofirst-order and pseudo-second-order models, higher values of $\mathrm{R}^{2}$ were found and the calculated values of $\mathrm{q}_{\mathrm{e}}$ were comparable to those of experimental values. Also, data exposed that, in general, the pseudo-second-order model was the more adequate to reproduce the experimental data. It indicates chemical adsorption onto phenol removal by SBFA [30]. Intraparticle diffusion model did not fit well to the process of adsorption of phenol due to the low values of $\mathrm{R}^{2}$ obtained, especially for temperatures of 27 and $40{ }^{\circ} \mathrm{C}$. Intraparticle diffusion model fitted the experimental results in a lower degree.

Table 4: Kinetic parameters for the adsorption of phenol on SBFA.

\begin{tabular}{|l|l|l|l|l|}
\hline \multirow{2}{*}{ Models } & \multirow{2}{*}{ Parameters } & \multicolumn{3}{|c|}{ Temperature } \\
\cline { 2 - 5 } & & $\mathbf{2 7}{ }^{\circ} \mathbf{C}$ & $\mathbf{4 0}^{\circ} \mathbf{C}$ & $\mathbf{6 0}^{\circ} \mathbf{C}$ \\
\hline \multirow{2}{*}{$\begin{array}{l}\text { Pseudo-first- } \\
\text { order }\end{array}$} & $k_{l}\left(\mathrm{~min}^{-1}\right)$ & 0.21 & 0.30 & 0.19 \\
\cline { 2 - 5 } & $q_{e}$ Calc. $(\mathrm{mg} / \mathrm{g})$ & 3.08 & 3.17 & 2.26 \\
\cline { 2 - 5 } & $R^{2}$ & 0.998 & 0.988 & 0.968 \\
\hline \multirow{2}{*}{$\begin{array}{l}\text { Pseudo- } \\
\text { second-order }\end{array}$} & $k_{2}(\mathrm{~g} / \mathrm{mg} \cdot \mathrm{min})$ & 0.13 & 0.26 & 0.14 \\
\cline { 2 - 5 } & $q_{e} \mathrm{Calc}(\mathrm{mg} / \mathrm{g})$ & 3.27 & 3.30 & 2.46 \\
\cline { 2 - 5 } & $R^{2}$ & 0.999 & 0.999 & 0.998 \\
\hline \multirow{2}{*}{$\begin{array}{l}\text { Intraparticle } \\
\text { diffusion }\end{array}$} & $k_{i d}\left(\mathrm{mg} / \mathrm{g} \cdot \mathrm{min}^{1 / 2}\right)$ & 0.20 & 0.13 & 0.16 \\
\cline { 2 - 5 } & $C(\mathrm{mg} / \mathrm{g})$ & 1.93 & 2.45 & 1.32 \\
\cline { 2 - 5 } & $R^{2}$ & 0.665 & 0.641 & 0.771 \\
\hline
\end{tabular}

Source: Authors, (2020).

According to some previous works, temperature has an evident influence on adsorption of both gas and liquid substances The maximum sorption capacity $\mathrm{q}_{\mathrm{e}}$ calculated from pseudo-first and pseudo-second order models decreased as the temperature increased, mainly when temperature changed from 27-40 to 60 ${ }^{\circ} \mathrm{C}$. Some authors [31-33], reported that, when the temperature increased, the attraction between the adsorbate and the active groups of the solid surface weaken and there was a greater inclination of the adsorbate to discharge from the solid surface towards the liquid phase, which causes a drop in adsorbate adsorption.

\section{III.2 COLUMN ADSORPTION STUDY}

Studies of adsorption in fixed-bed or packed-bed columns are indispensable for the scale-up of the adsorption processes [3435]. In this sense, to determine the kinetic parameters that characterizes dynamic adsorption is important carry out research that lets determinate the corresponding breakthrough curves.

In the Figures 5 and 6 , the breakthrough curves show saturation times from 110 and $150 \mathrm{~min}$ for 47.5 and $65.0 \mathrm{~g}$ respectively.

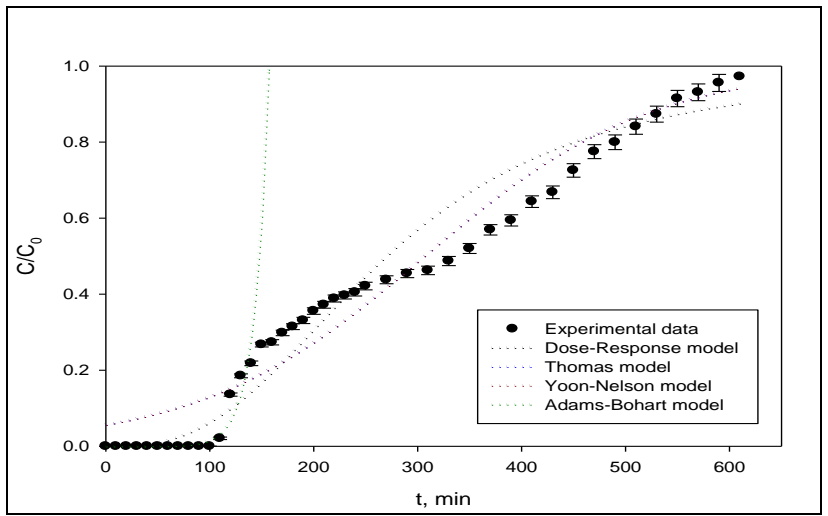

Figure 5: Non-linear plot of Thomas, Yoon-Nelson, Adams-Bohart and Dose-response models for the adsorption of phenol using $47.5 \mathrm{~g}$ of SBFA.

Source: Authors, (2020). 


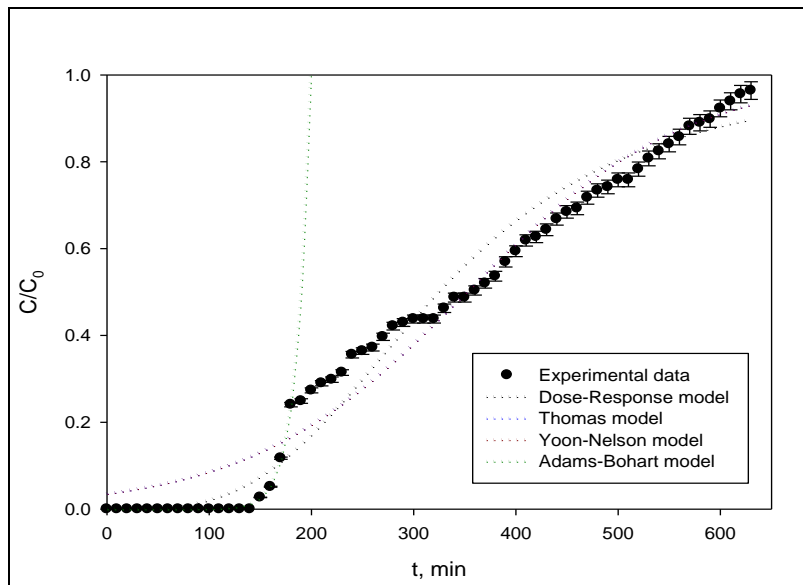

Figure 6: Non-linear plot of Thomas, Yoon-Nelson, Adams-Bohart and Dose-response models for the adsorption of phenol using $65.0 \mathrm{~g}$ of SBFA.

Source: Authors, (2020).

Table 5 shows the parameters calculated from the kinetic models, applied to the breakthrough curves, for both experiments performed with different weight of adsorbent.

Table 5: Kinetics parameters in dynamic conditions for the adsorption of phenol on SBFA.

\begin{tabular}{|c|c|c|c|c|c|}
\hline Models & \multicolumn{5}{|c|}{ Parameters } \\
\hline \multirow{3}{*}{ Dose-response } & $\boldsymbol{m}(a s h)(g)$ & $A$ & $\boldsymbol{q}_{\mathbf{0}}(\mathrm{mg} / \mathrm{g})$ & $R^{2}$ & \\
\hline & 47.5 & 2.72 & 0.34 & 0.867 & \\
\hline & 65.0 & 3.26 & 0.30 & 0.908 & \\
\hline \multirow{3}{*}{ Thomas } & & $\boldsymbol{k}_{\boldsymbol{T H}}(\mathrm{mL} / \mathrm{min} \cdot \mathrm{mg})$ & $\boldsymbol{q}_{\mathbf{0}}(\mathrm{mg} / \mathrm{g})$ & $R^{2}$ & \\
\hline & 47.5 & 0.00184 & 0.39 & 0.896 & \\
\hline & 65.0 & 0.00187 & 0.32 & 0.917 & \\
\hline \multirow{3}{*}{ Yoon-Nelson } & & $\boldsymbol{k}_{Y N}\left(\min ^{-1}\right)$ & $\boldsymbol{\tau}$ (min) calc. & $R^{2}$ & $\boldsymbol{\tau}(\min ) \exp$. \\
\hline & 47.5 & 0.0092 & 306.3 & 0.896 & 330 \\
\hline & 65.0 & 0.0094 & 351.5 & 0.917 & 360 \\
\hline \multirow{3}{*}{ Adams-Bohart } & & $\boldsymbol{k}_{\boldsymbol{A} \boldsymbol{B}}(\mathrm{L} / \mathrm{mg} \cdot \mathrm{min})$ & $N o(m g / L)$ & $R^{2}$ & \\
\hline & 47.5 & 0.0146 & 90.62 & 0.765 & \\
\hline & 65.0 & 0.0148 & 88.55 & 0.998 & \\
\hline
\end{tabular}

Source: Authors, (2020).

According to the results obtained for Dose-response and Thomas models, as the bed height increased, the amount of phenol removed by gram of SBFA, qo, decreased. In addition, if the values obtained of $\mathrm{q}_{0}$ for Dose-response and Thomas models are compared, very similar values are found.

The Thomas and Yoon-Nelson fitted better the full experimental breakthrough curve. Adams-Bohart model also represents the sorption of phenol accurately for the initial part of the breakthrough curve and fitted better for the highest mass of adsorbent studied. In all the cases, $\mathrm{R}_{2}$ and the rate constant values increased with an increase in the sorbent mass, due to increase of the height of the mass transfer zone. Regards the parameter $\tau$ of Yoon-Nelson model (the half-life of adsorbate breakthrough) it did not show important differences between the calculated values and the experimental ones.

\section{CONCLUSIONS}

From the results obtained it can be concluded that the sorption process occurs quickly, reaching the maximum sorption capacity before 20 minutes of operation, being slightly more favorable at temperatures between 27 and $40{ }^{\circ} \mathrm{C}$.

The kinetics of adsorption of phenol using SBFA as adsorbent in batch systems was well described by pseudo-first order and pseudo-second order models with $\mathrm{R}^{2}$ values higher than
0.99 in both models, which suggests that adsorption process was well defined by chemisorption.

The kinetic models used to predict the adsorption of phenols in fixed-bed columns, Thomas, Yoon-Nelson, Adams-Bohart and Dose-response models, fitted well to the experimental breakthrough curves. Although, Adams-Bohart model was only able to predict the initial part of the curve.

\section{ACKNOWLEDGMENTS}

The authors are thankful to the Chemical - Pharmacy Faculty of the Central University "Marta Abreus" of Las Villas, UCLV and to the "Centro de Estudios Ambientales de Cienfuegos", for providing all necessary technologies and infrastructure for carrying out this work.

\section{REFERENCES}

[1] Moyo M, Mutare E, Chigondo F, Nyamunda BC. Removal of phenol from aqueous solution by adsorption on yeast, Saccharomyces Cerevisiae. IJRRAS 2012;11(3):486-94.

[2] McKay, G., Dehghani, M.H., Alimohammadi, M., Sahu, J.N., Heibati, B. Mubarak, N.M., Mostofi, M., Yetilmezsoy, K., Albadarin, A.B., AlGhouti, M. High-performance removal of toxic phenol by single-walled and multi-walled carbon nanotubess: kinetics, adsorption, mechanism and optimization studies. J. Ind. Eng. Chem. 2015:35: 63-74. https://doi.org/10.1016/j.jiec.2015.12.010 
[3] Zeng, Z., Zou, H., Li, X., Arowo, M., Sun, B., Chen, J., Chu, G., Shao, L. Degradation of phenol by ozone in the presence of Fenton reagent in a rotating packed bed. Chem. Eng. J. 2013:229: 404-411. https://10.1016/j.cej.2013.06.018

[4] Alves, D.C.S., Gonçalves, J.O., Coseglio, B.B., Burgo, T.A.L., Dotto, G.L., Pinto, L.A.A., Cadaval Jr., T.R.S. Adsorption of phenol onto chitosan hydrogel scaffold modified with carbon nanotubes. Journal of Environmental Chemical Engineering 2019:7(6):103460. https://doi.org/10.1016/j.jece.2019.103460

[5] Mohanty K, Jha M, Meikap BC, Biswas MN. Preparation and Characterization of Activated Carbons from Terminalia Arjuna Nut with Zinc Chloride Activation for the Removal of Phenol from Wastewater. Indian Engineering Chemical Research. 2005;44:4128-38. https://doi.org/10.1021/ie050162+

[6] Karunarathne HDSS, Amarasinghe BMWPK. Fixed Bed Adsorption Column Studies for the Removal of Aqueous Phenol from Activated Carbon Prepared from Sugarcane Bagasse. Energy Procedia. 2013;34(0):83-90. https://doi.org/10.1016/j.egypro.2013.06.736

[7] Shou J, Qiu M. Adsorption kinetics of phenol in aqueous solution onto activated carbon from wheat straw lignin. Desalination and Water Treatment. 2014;1-6. https://doi.org/10.1080/19443994.2014.966328

[8] Tao H.-C., Zhang H.-R., Li J.-B., Ding W.-Y. Biomass based activated carbon obtained from sludge and sugarcane bagasse for removing lead ion from $\begin{array}{llll}\text { wastewater. } & \text { Bioresour. } & \text { Technol. } & \text { 2015;192:611-617. }\end{array}$ https://doi.org/10.1016/j.biortech.2015.06.006

[9] Carrier M., Hardie A.G., Uras Ü, Görgens J., Knoetze J.H. Production of char from vacuum pyrolysis of South-African sugar cane bagasse and its characterization as activated carbon and biochar. J. Anal. Appl. Pyrol. 2012;96:24-32. https://doi.org/10.1016/j.jaap.2012.02.016

[10] Karri R.R., Sahu J.N., Meikap B.C. Improving efficacy of Cr (VI) adsorption process on sustainable adsorbent derived from waste biomass (sugarcane bagasse) with help of ant colony optimization. Industrial Crops and Products 2020;143: 111927. https://doi.org/10.1016/j.indcrop.2019.111927

[11] Bahurudeen A., Santhanam M. Influence of different processing methods on the pozzolanic performance of sugarcane bagasse ash. Cem Concr Compos 2015;56:32-45. https://doi.org/10.1016/j.cemconcomp.2014.11.002

[12] Deepika S., Anand G., Bahurudeen A., Manu Santhanam M. Construction products with sugarcane bagasse ash binder. J Mater Civil Eng 2017;29:04017189. https://doi.org/10.1061/(ASCE)MT.1943-5533.0001999

[13] MolinFilho R.G.D., Longhi D.A., De Souza R.C.T., Ferrer M.M., Vanderlei .RD., Paraíso P.R., de Jorge L.M.M. Self-compacting mortar with sugarcane bagasse ash: development of a sustainable alternative for Brazilian civil construction. Environ Dev Sustain. 2018 https://doi.org/10.1007/s10668-0180127-x (in press) https://doi.org/10.1007/s10668-018-0127-x

[14] Molin Filho, R.G.D., Colpini, L.M.S., Ferrer, M.M., Nagano, M.F., Rosso, J.M., Volnistem, E.A., Paraíso, P.R., Jorge, L.M.M. Characterization of different sugarcane bagasse ashes generated for preparation and application as green products in civil construction. Clean Techn Environ Policy 2019; 21: 1687. https://doi.org/10.1007/s10098-019-01740-x

[15] Rodríguez-Díaz JM, Prieto García JO, Bravo Sánchez LR, Carlos da Silva MG, Lins da Silva V, Arteaga-Pérez LE. Comprehensive Characterization of Sugarcane Bagasse Ash for Its Use as an Adsorbent. Bioenerg Res. 2015. https://doi.org/10.1007/s12155-015-9646-6

[16] Srivastava VC, Swamy MM, Mall ID, Prasad B, Mishra IM. Adsorptive removal of phenol by bagasse fly ash and activated carbon: Equilibrium, kinetics and thermodynamics. Colloids and Surfaces A: Physicochemical and Engineering Aspects. 2006 Jan 5;272:89-104. https://doi.org/10.1016/j.colsurfa.2005.07.016

[17] Abdel-Ghani NT, El-Chaghaby GA, Helal FS. Individual and competitive adsorption of phenol and nickel onto multiwalled carbon nanotubes. Journal of Advanced $\quad$ Research. $2015 \quad$ May;6(3):405-15. https://doi.org/10.1016/j.jare.2014.06.00

[18] ASTM Designation: D 1783 - 01 Standard Test Methods for Phenolic Compounds in Water. 2001

[19] Lagergren S. Zur theorie der sogenannten adsorption geloster stoffe. Kungliga Svenska Ventenskapsaka demiens Handlingar. 1898;24(4):1-39.
[20] Ho YS, McKay G. Pseudo-second order model for sorption processes Process Biochemistry. 1999 Jul;34(5):451-65. https://doi.org/10.1016/S0032 9592(98)00112-5

[21] Ho Y. S. and Mckay, G., The kinetics of sorption of divalent metal ions onto sphagnum moss peat, Water Research, 34, No. 3, 735-742 (2000) https://doi.org/10.1016/S0043-1354(99)00232-8

[22] Weber, W. J. and Morris, J. C., Kinetic of adsorption on carbon from solution, Journal of Sanitary Engineering Division, Proceedings of the American Society of Civil Engineers, 89, 31-60 (1963)

[23] Bohart, G.S., Adams, E.Q., 1920. Some aspects of the behavior of charcoa with respect to chlorine. J. Am. Chem. Soc. 42, 523-544. https://doi.org/10.1021/ja01448a018

[24] Thomas, H.C., 1944. Heterogeneous Ion Exchange in a Flowing System. J. Am. Chem. Soc. 66, 1664-666. https://doi.org/10.1021/ja01238a017

[25] Yoon, Y.H., Nelson, J.H., 1984. Application of Gas Adsorption Kinetics I. A Theoretical Model for Respirator Cartridge Service Life. Am. Ind. Hyg. Assoc. J. 45, 509-516. https://doi.org/10.1080/15298668491400197

[26] Yan, G., Viraraghavan, T., Chen, M., 2001. A new model for heavy metal removal in a biosorption column. Adsorpt. Sci. Technol. 19, 25-43. https://doi.org/10.1260/0263617011493953

[27] Moussout H, Ahlafi H, Aazza M, Maghat H. Critical of linear and nonlinear equations of pseudo-first order and pseudo-second order kinetic models. Karbala International Journal of Modern Science. 2018 Jun 1;4(2):244-54 https://doi.org/10.1016/j.kijoms.2018.04.001

[28] Subramanyam B, Das A. Study of the adsorption of phenol by two soils based on kinetic and isotherm modeling analyses. Desalination. 2009 Dec 25;249(3):914-21. https://doi.org/10.1016/j.desal.2009.05.020

[29] Tan KL, Hameed BH. Insight into the adsorption kinetics models for the removal of contaminants from aqueous solutions. Journal of the Taiwan Institute of Chemical Engineers. 2017 May 1;74:25-48 https://doi.org/10.1016/j.jtice.2017.01.024

[30] Moreno-Piraján JC, Giraldo L, Gonzalez JF. Adsorción de Fenol en soluciones acuosas empleando monolitos de carbón activado de cáscara de Coco: isotermas y cinéticas de adsorción. AFINIDAD. 2011;554:290-5.

[31] Chen, S., Jin, L., Chen, X. The effect and prediction of temperature adsorption capability of coal/CH4. Procedia Engineering 2011;26:126-131 https://doi.org/10.1016/j.proeng.2011.11.2149

[32] Ofomaja, A.E., Ho, Y.-S. Effect of temperatures and $\mathrm{pH}$ on methyl violet biosorption by Mansonia wood sawdust. Bioresource Technology 2008; 99(13:5411-5417. https://doi.org/10.1016/j.biortech.2007.11.018

[33] Al-Homaidan, A.A., Al-Houri, H.J., Al-Hazzani, A.A., Elgaaly, G., Moubayed, N.M.S. Biosorption of copper ions from aqueous solutions by Spirulina platensis biomass. Arabian Journal of Chemistry 2014;7(1):57-62. https://doi.org/10.1016/j.arabjc.2013.05.022

[34] Preetha, B., Viruthagiri T. Batch and continuous biosorption of chromium(VI) by Rhizopus arrhizus. Separation and Purification Technology. 2007;57:126-33. https://doi.org/10.1016/j.seppur.2007.03.015

[35] Fernández-González, R.; Martín-Lara, M.A.; Moreno, J.A.; Blázquez, G.; Calero, M. Effective removal of zinc from industrial plating wastewater using hydrolyzed olive cake: scale-up and preparation of zinc-based biochar. Journal of Cleaner Production 2019;227:634-644. https://doi.org/10.1016/j.jclepro.2019.04.195 